\title{
Measuring Comparative Advantages in the Euro Area
}

\author{
Ioanna Konstantakopoulou ${ }^{1}$
}

Mike G. Tsionas ${ }^{2}$

\begin{abstract}
This paper investigates the relationship between comparative advantages and exports specialization. Panel unit root tests, panel cointegration test, and panel causality tests are used to examine this relationship. We also use panel estimation methods that mitigate heterogeneity, cross-sectional dependence, and endogeneity. The empirical analysis is based on annual data of the Euro Area for the period 1995-2016. We detect strong export competitiveness in the Netherlands, Belgium, France, and Spain. The recent financial crisis has affected the export competitiveness of countries, improving it significantly in Portugal, Finland, Austria, and the Netherlands, while worsening it mainly in Greece, Belgium, Slovakia, Spain, and France. The empirical results indicate that comparative advantages positively affect export specialization. Heterogeneous panel causality analysis results support that there is unidirectional panel causality running from comparative advantages to export specialization in Austria, Belgium, Cyprus, Estonia, Finland, France, Germany, Latvia, the Netherlands, Slovenia, and Spain; and the reserved causal relation in Greece, Italy, and Portugal. Finally, we detect bidirectional panel causality between comparative advantages and export specialization in Ireland, Lithuania, Malta, and Slovakia.
\end{abstract}

\section{Keywords:}

Exports competitiveness

Comparative Advantages

Panel Granger Causality

FMOLS, CCE-MG, CCE-PMG, and GMM estimator

JEL Classifications: C23; E00; F14

\footnotetext{
${ }^{1}$ Centre for Planning and Economic Research, 11 Amerikis Street, 10672 Athens, Greece. ik@kepe.gr.

2 Lancaster University Management School LA1 4YX, U.K. m.tsionas@lancaster.ac.uk
} 


\section{Introduction}

An important issue in economics is the identification of factors that affect the pattern of trade. In the early nineteenth century, David Ricardo argued that all countries could benefit from participating in international trade. The Ricardian theory of comparative advantage (CA) focuses on the differences in labor productivity between countries, as the factor that creates the comparative advantages of countries, while technology is considered as an exogenous variable. Later, the Heckscher and Ohlin model underlined the differences in each country's proportions of factor endowment in determining CAs.

Recent trade theories, such as Krugman's (1987) consider the initial endowment of 'cumulative' production experience in a specific sector as the crucial factor of the export performance of an economy. The endowment of cumulative experience is formed through continuous learning by doing, where, although learning is diffused across countries, in practice it remains imperfect. Krugman showed that initial endowments of two economies determine the initial structure of their CAs and international specialization. Thus, over time initial endowments "lock" every economy in sectors in which it has already accumulated manufacturing experience and not in other sectors, where it has less or no experience. Young (1991) pointed out that trade between countries is the result of differences in technology and knowledge rather than the result of differences in available resources. Grossman and Helpman (1991), and Rivera-Batiz and Romer (1991a, b), emphasized the differences in technology, $\mathrm{R} \& \mathrm{D}$, and knowledge diffusion, for determining the CAs of each country, providing a model that adopted several assumptions of the Heckscher-Ohlin theory with endogenous technology (Schumpeterian model). Trefler (1995) noted the importance of technological differences and factor endowments in determining the trade patterns of countries. Eaton and Kortum (2002), Romalis (2004), Costinot et. al (2012), Arkolakis et. al. (2012), and Levchenko and Zhang (2016) detected the sources of CAs in terms of technological differences, productivity and endowments. Kerr (2013), and Chor (2010) underlined the importance of total productivity of inputs for forming CAs. Furthermore, institutional quality (Levchenko, 2007, Costinot, 2009, Nunn and Trefler, 2014), worker's human capital or distribution of worker skills (Costinot, 2009, Ohnsorge and Trefler, 2007) and labor market institutions (Cuñat and Melitz, 2012) are identified as sources of CAs.

In practice, measuring CAs of sectors using competitiveness indicators is not by any means easy. Balassa (1965) proposed the Revealed Comparative Advantage (RCA) index for identifying the "revealed" CAs of a country. The Balassa index is based on the relative shares of a country in the world exports (or reference countries) of individual commodities. Balassa 
and Noland (1989) examine the changes of CAs of industrial products in Japan, and the United States, in the period 1967-1983. Richardson and Zhang (1999) used the methodology of the RCA, for the United States, in the period 1980-1995. They mapped US comparative advantages, by trading partner and region. They found that in differentiated producer goods, comparative advantages are temporally stable and ubiquitous; in standardized producer goods, the RCA is somewhat less stable while it is chaotic and has diverse patterns RCA in consumer goods. In addition, the most important finding is sharp geographical differences in patterns of US RCA and surprisingly small differences across sub-sectors of one, two, and three-digit SITC classifications. Yue and Hua (2002) applied a similar methodology for China, in 19901998, to examine whether CAs explain increased exports. Their econometric findings showed the existence of a positive relationship between comparative advantages in heavy industry sectors and exports. Lee (2011) used the Balassa index with regression analysis to examine whether the composition of exports (focusing on technology intensive industries) affects economic growth. Using a sample of 71 countries, he showed that economies grow faster when they are specialized in exporting high-tech products than when specializing in traditional or low-tech product products. Deb and Basu (2011) examined the consistency of alternative RCA indicators with the Heckscher-Ohlin theory. Bojnec and Ferto (2014) examined the competitiveness of the agri-food sector in European Union countries (EU-27) based on the RCA index. At the firms level, Bernard et al. (2007), showed that the effects of symmetric trade liberalization on a given country are different for comparative-advantage and comparative disadvantage (CD) industries, so that resource reallocation takes place across firms within the same industry as well as between industries. Mallick and Marques (2016) investigated the role of product-level CA in exporters' pricing strategies. Furthermore, they emphasized that CAs play an important role in relating exchange rate changes to price variations in the buyers' currency.

Eurozone exports accounted for $29.48 \%$ of total world exports in the period 1995-2016 (25.9\% and $30.9 \%$ in $2009-14$, and 2000-08, respectively) ${ }^{3}$ However, the export performance of the Euro Area in recent years has worsened. Exports have undoubtedly been influenced by the striking slowdown in global trade and economic recession in the main trading partners. In addition, the proportion of exports in economic activity differs widely among Euro Area countries. In particular, we observe a high contribution of exports to GDP in the Netherlands, Ireland, Belgium, and new Euro Area entrants (Slovakia, Lithuania, Slovenia, Estonia, and

\footnotetext{
${ }^{3}$ Source: UNCTAD.
} 
Latvia), as well as in Austria, followed by Germany4. In contrast, the Euro Area's southern countries show a lower contribution of exports to GDP. Undoubtedly, there are different export patterns in the Euro Area. The latter feature comes from the differences in export competitiveness across countries. In most cases, the level of export competitiveness was the determining factor of the external imbalance in the euro area economies. Imbalances within the eurozone are observed between the north and south, as the southern countries have accumulated large deficits, and the Northern economies have large surpluses (Esposito, 2017, and Nieminen, 2015). The recent euro area sovereign debt crisis has highlighted the problems that these imbalances create in the current account. The current account deficits signal rising external indebtedness that can create serious economic problems. Thus, suffering from large and persistent current account deficits, these countries face the challenge of improving their external competitiveness.

The purpose of this paper is to investigate the relationship between export specialization and comparative advantages in Eurozone economies. Moreover, we test the direction of causality relationship between these variables. It is important to understand this causality relationship. If comparative advantages do matter for export specialization, governments should follow policies that can promote and enhance comparative advantages, to boost the level of exports ${ }^{5}$. In particular, governments could motivate the exporting firms through subsidies, to invest in $R \& D$, human and physical capital, or provide grants to encourage exporting firms to compete more effectively in international markets (Gorg et al. 2008) or adopt programs to overcome the default risk and credit constraints that appeared during the recent crises.

Additional objectives of our paper are to examine the competitiveness of exports; to investigate the stability of the export specialization patterns; and to investigate whether the recent financial crisis affected the competitive position of exporting sectors.

This study fills a gap in the empirical literature of export competitiveness in the Euro Area. It comes in a timely manner as recently some have voiced their request in favor of a more protectionist approach to world trade. Moreover, the length of the sample of empirical analysis allows us to examine the effects of the recent financial crisis on competitiveness which is quite important for policy analysis. By exploring the export competitiveness of all sectors for each Eurozone country, one can assist European policy-makers in better understanding the different patterns of export specialization in the Euro Area. We apply econometric techniques that

\footnotetext{
${ }^{4}$ Source: Eurostat.

5 Exports have been established as a stimulated variable of economic growth in many studies (Kunst and Marin 1992, Ramos 2001, Konya 2006, Konstantakopoulou 2016, and Konstantakopoulou and Tsionas, 2017).
} 
allow heterogeneity across countries, the presence of cross-sectional dependence as well as endogeneity.. Specifically, we make use of the panel Fully Modified OLS estimator (FMOLS) developed by Pedroni (2000), the Common Correlated Effects Mean Group estimator (CCE-MG) suggested by Pesaran (2006), the Dynamic CCE Pooled Mean Group estimator (CCE-PMG) suggested by Chudik and Pesaran (2015), and the panel Generalized Method of Moments GMMSystem estimator with instrumental variables (IV) developed by Arellano and Bover (1995). The empirical results indicate that comparative advantages have positive and significant impact on export specialization in the Euro Area economies. In particular, there is a unidirectional causal relationship from comparative advantage to export specialization.

We proceed as follows. In Section 2, we describe the data and the methodologies employed. In Section 3, we report the empirical results, i.e. the CAs of two-digit sectors, export specialization, and the stability of export patterns. In section 4, we investigate the relationship between the variables. Section 5, we summarize our findings.

\section{Data and Methodology}

The statistical data come from Comtrade (United Nations Commodity Trade Statistics Database), UNCTAD (United Nations Conference on Trade and Development), and Eurostat for the period 1995-2016. In some parts of our analysis, we divide the sample period into two sub-periods, 2000-08 and 2009-2014. The sample includes the following Euro Area (EA) countries: Austria (denoted AT), Belgium (BE), Cyprus (CY), Estonia (EE), Finland (FI), France (FR), Germany (DE), Greece (GR), Ireland (IE), Italy (IT), Latvia (LV), Lithuania (LT), Malta (MT), the Netherlands (NL), Portugal (PT), Slovakia (SK), Slovenia (SI), and Spain (ES). For the analysis by sector, we use data of export and import flows (in value) in two-digit classification level according to the SITC (Standard International Trade Classification, Rev.3). The two-digit SITC classification includes 63 sectors. To present our empirical results, we classify these sectors into three main groups $^{6}$ : (i) industrial products, (ii) raw materials and mineral fuels, and (iii) agricultural products.

The main component of Euro Area exports is industrial products, which is followed by agricultural products. We find that the export shares of fuels and raw materials are much smaller

\footnotetext{
${ }^{6}$ The Group of industrial products includes 35 two-digit SITC sectors of the one-digit SITC sectors: Chemicals and related products (SITC 5), Manufactured goods classified chiefly by material (SITC 6), Machinery and transport equipment (SITC 7), and Miscellaneous manufactured articles (SITC 8). The Group of Agricultural products includes 15 two-digit SITC sectors of the one-digit SITC sectors: Food and live animals (SITC 0), Beverages and tobacco (SITC 1), and Animal and vegetable oils, fats and waxes (SITC 4). The Group of Mineral fuels and Raw materials includes 13 two-digit SITC sectors of the one-digit SITC sectors: Crude materials, inedible, except fuels (SITC 2), and Mineral fuels, lubricants and related materials (SITC 3).
} 
than those of industrial and agricultural products, in most countries. Regarding the export patterns by one-digit SITC sectors, Machinery and Transport Equipment (SITC 7) is the largest exporting one-digit sector of the Euro Area in the period 1995-2016. High export share is observed in Manufactured Goods classified chiefly by Materials (SITC 6), Chemicals and Related Products (SITC 5), and Miscellaneous Manufactured Articles (SITC 8). These are followed by Food and Live Animals (SITC 0), and the Mineral Fuels, Lubricants and Related Materials (SITC 3).

\subsection{The Revealed Symmetric Comparative Advantage Index}

To measure CAs, we use the RCA index of Balassa (1965). This index has received several criticisms because it is not symmetrical. Laursen (1998, 2000), and Dalum et. al. (1998) deal with this problem by suggesting the Revealed Symmetric Comparative Advantage Index (RSCA). The RSCA index, is a transformation of the RCA index that has the following form:

$$
R S C A_{k}^{i}=\left(R C A_{k}^{i}-1\right) /\left(R C A_{k}^{i}+1\right)
$$

where $R C A_{k}^{i}=\frac{\mathrm{X}_{\mathrm{k}}^{i} / \sum_{k} \mathrm{X}_{k}^{i}}{\sum_{i} X_{k}^{i} / \sum_{i} \sum_{k} X_{k}^{i}}$, for $i=1,2, \ldots . .16, k=1,2, \ldots \ldots .63$

$R S C A_{k}^{i}$ is the revealed symmetric CA of country $i$ in sector $k, X_{k}^{i}$ is country $i$ ' export value of sector $k, \sum_{k} X_{k}^{i}$ is the total exports of country $i, \sum_{i} X_{k}^{i}$ is the total exports of EA- 18 countries in sector $k$, and $\sum_{i} \sum_{k} X_{k}^{i}$ is the total exports of EA- 18. The interpretation of the RSCA index is similar to that of conventional indexes, with the difference that values range from $[-1,1]$, where $0<R S C A_{k}^{i} \leq 1$ implies that country $i$ has a comparative advantage for sector $k$, while $-1 \leq R S C A_{k}^{i}<0$ implies that country $i$ has a CD for sector $k$. A zero value, indicates that the country has no CA or CD. The calculation of the CAs is carried out in the two-digit SITC sectors of each Euro Area countries, using the RSCA index. In addition, the degree of competitiveness is measured directly by the RSCA Index.

\subsection{The Trade Balance Index}

To investigate export specialization, i.e. the different patterns of specialization in the Euro Area, we use the Trade Balance Index (TBI), which is described via the following equation:

$$
\mathrm{TBI}_{k}^{i}=\left(X_{k}^{i}-M_{k}^{i}\right) /\left(X_{k}^{i}+M_{k}^{i}\right)
$$


where $M_{k}^{i}$ are the imports of country $i$ for sector $k$. The value of the index varies in the interval $[-1,1]$. If $\mathrm{TBI}_{k}^{i}=-1$, then a country only has imports, while if $\mathrm{TBI}_{k}^{i}=1$ then a country only has exports. Values between -1 and 1 imply that a country imports and exports simultaneously. A country is considered as a net importer (weak export specialization) and therefore is not specialized in trade in a sector, when the index is negative. In contrast, the country is considered as a net exporter (strong export specialization), and therefore specialized in production in a specific sector, when the index is positive. Finally, when the TBI index is positive, this means that there is a positive balance or surplus for this sector and vice versa.

\subsection{Stability of export specialization}

We investigate the stability of the export specialization pattern at the country level. We follow the methodology of Dalum et. al (1998), which has its origins in an article by Cantwell (1989). The stability of export specialization (specialization trends) is tested by the following convergence regression equation for each country in the Euro Area:

$$
R S C A_{i j}^{t 2}=\alpha_{j}+\beta_{j} R S C A_{i j}^{t 1}+\varepsilon_{i j}
$$

The superscripts $t_{1}$ and $t_{2}$ refer to the initial period and final period, respectively. We estimate equation (3) for three time periods (i) 2000-08 and 2009-14, (ii) 2000-08 and 2008-14, and (iii) 2000-09 and 2009-14. The dependent variable, RSCA at period $t_{2}$ for sector $j$ of country $i$, is regressed on the value of RSCA in period $t_{1}\left(t_{1}<t_{2}\right)$. Moreover, $\alpha$ and $\beta$ are regression coefficients, and $\varepsilon_{i j}$ is the regression error. According to Dalum et al. (1998), we have the following results:

(a) if, $\beta=1$, the pattern of export specialisation remains stable, i.e. the CAs of the sectors from $t_{1}$ to $t_{2}$ remain unchanged, presenting no differentiation,

(b) if $\beta>1$, the country tends to be more specialised in sectors in which it is already specialised, and less specialised where initial specialisation is low, which means that the existing pattern of specialization is strengthened (i.e. $\beta$-specialization),

(c) and if $0<\beta<1$, the country tends to change its specialisation pattern between periods (i.e. there is $\beta$-de-specialization), which means that on average, sectors with initial low values in the RSCAs tend to increase over time, while sectors with initial high RSCA decrease their values.

The term $(1-\beta)$ is known as "regression to the mean effect". When $\beta$ is negative, the ranking of sectors is reversed, as sectors with RSCA below the average of the country during the first 
period are above the average in the second period, and vice versa. Therefore, based on the above, we conclude that it is fundamental to test whether $\hat{\beta}$ is greater than zero, because if $\hat{\beta} \leq 0$, we cannot reject that the development in export specialisation models was either due to chance or reversed.

Degree of specialization: Furthermore, another feature that can be extracted from the regression analysis concerns the intensity/extent of change in specialization over time. Particularly, according to Cantwell (1989), if $\beta>1$, this is not a necessary condition for an increase in the structure of a country's specialization. Therefore, we should examine the RSCA variance fraction in the two sub-samples. Specifically, Hart (1976) showed that:

$$
\sigma_{i}^{t_{2}} / \sigma_{i}^{t_{1}}=\beta_{i}^{2} / R_{i}^{2} \text { thus, } \sigma_{i}^{t_{2}} / \sigma_{i}^{t_{1}}=\left|\beta_{i}\right| /\left|R_{i}\right| \text {, }
$$

where $\sigma^{2}$ is the dispersion of RSCA and $R$ is the square rootr of the coefficient of determination. If the dispersion remains unchanged, we have: $\beta=R$. Therefore, the degree of specialisation should remain stable between the two subperiods. If $\beta>R$ the degree of specialization increases (i.e. we have $\beta$-specialization). If $\beta<R$ the degree of specialization decrease (i.e. we have $\beta$-despecialization). In addition, $\mathrm{R}$ is a measure of mobility in the RSCA distribution. Specifically, $(1-R)$ measures the mobility effect. A high value of this coefficient indicates that the relative position of sectors is little changed, while a low level indicates that the ranking of sectors changes. We should note that even when the regression effect $(1-\beta)$ suggests a decrease in the degree of specialization due to a change in sectors towards the average, this is offset by the effect of mobility, due to changes in the relative position between sectors $(\beta>R)$. Table 1 summarizes the expressions used both in the growth and the trade specialization literature.

Table 1: Classification of the Expressions

\begin{tabular}{|l|l|l|}
\hline $\boldsymbol{\beta}=1$ or $\boldsymbol{\beta}=\boldsymbol{R}$ & No change & No change \\
\hline $\boldsymbol{\beta}>\mathbf{1}$ or $\boldsymbol{\beta}>\boldsymbol{R}$ & Specialization & Divergence \\
\hline $\boldsymbol{0}<\boldsymbol{\beta}<\mathbf{1}$ or $\boldsymbol{0}<\boldsymbol{\beta}<\boldsymbol{R}$ & De-specialization & Convergence \\
\hline
\end{tabular}

\section{Empirical Results}

\subsection{Comparative advantages}

Table 2 presents the share of two-digit SITC sectors with CAs in the total of sectors and in each group of products (Agricultural products, Mineral fuels and Raw Materials, and Industrial product). We detect strong export competitiveness in the Netherlands, Belgium, France, and Spain. We observe that economies with high export performance accumulate CAs in industrial sectors. An interesting question is whether the sub-prime crisis has affected export 
competitiveness in any substantive ways. In Table 3, we present the evolution of export competitiveness for two-digit sectors of each country. Specifically, we have a remarkable improvement of Portugal's export competitiveness position between two sub-periods (20002008, and 2009-2014), which reaches 73\% of all its two-digit sectors. The same behavior is observed in Finland, Austria, the Netherlands, Estonia, Latvia, and Ireland. In contrast, the greatest losses in export competitiveness are recorded in Greece, Belgium, Slovakia, Spain, France, and Cyprus.

Table 2: Distribution of the sectors with CA (1995-16) (shares in total sectors)

\begin{tabular}{lcccc}
\hline & $\begin{array}{c}\text { All sectors } \\
(\mathbf{2})\end{array}$ & $\begin{array}{c}\text { Agricultural } \\
\text { Products } \\
\mathbf{( 3 )}\end{array}$ & $\begin{array}{c}\text { Mineral fuels and } \\
\text { Raw materials }\end{array}$ & $\begin{array}{c}\text { Industrial } \\
\text { products } \\
\mathbf{( 5 )}\end{array}$ \\
\hline Austria & 31.75 & 1.59 & 6.35 & 23.81 \\
Belgium & 44.44 & 11.11 & 12.70 & 20.63 \\
Cyprus & 17.46 & 9.52 & 6.35 & 1.59 \\
Estonia & 33.33 & 4.76 & 11.11 & 17.46 \\
Finland & 25.40 & 0.00 & 6.35 & 19.05 \\
France & 41.27 & 14.29 & 7.94 & 19.05 \\
Germany & 26.98 & 1.59 & 1.59 & 23.81 \\
Greece & 31.75 & 12.70 & 9.52 & 9.52 \\
Ireland & 28.57 & 11.11 & 4.76 & 12.70 \\
Italy & 31.75 & 6.35 & 0.00 & 25.40 \\
Latvia & 28.57 & 9.52 & 7.94 & 11.11 \\
Lithuania & 38.10 & 14.29 & 12.70 & 11.11 \\
Malta & 14.29 & 4.76 & 1.59 & 7.94 \\
Netherlands & 47.62 & 20.63 & 14.29 & 12.70 \\
Portugal & 36.51 & 6.35 & 9.52 & 20.63 \\
Slovakia & 34.92 & 3.17 & 7.94 & 23.81 \\
Slovenia & 31.75 & 0.00 & 6.35 & 25.40 \\
Spain & 39.68 & 12.70 & 6.35 & 20.63 \\
\hline
\end{tabular}

Source: Authors' calculations based on Comtrade.

Note: Column 2 shows the share of sectors with CAs in the total sectors for the period 1995-2016. Columns 3-5 contain the shares of sectors with CAs in each product group (Agricultural, Mineral fuel and raw materials, and industrial sectors), respectively.

Table 3: Evolution of comparative advantages between 2000-08 and 2009-14

\begin{tabular}{ccccccccc}
\hline $\mathbf{A T}$ & BE & CY & DE & EE & ES & FI & FR & GR \\
\hline 57.14 & 28.57 & 42.86 & 47.62 & 55.56 & 31.75 & 68.25 & 33.33 & 25.40 \\
\hline IE & IT & LT & LV & MT & NL & PT & SK & SI \\
\hline 50.79 & 46.03 & 66.67 & 53.97 & 30.16 & 55.56 & 73.02 & 31.75 & 46.03 \\
\hline
\end{tabular}

Note: Row 2 and 4 shows the percentage of sectors out of all two-digit sectors, which have even marginally improved their export competitiveness (increased RSCA value) in relation to the 2000-08 period.

Source: Authors' calculations based on Comtrade.

\subsection{Export specialization}

The empirical evidence on export specialization of the two-digit SITC sectors is shown in Table 4. We detect two groups of countries; the first group includes countries with strong export specialization, such as the Netherlands, Germany, Belgium, Italy, and France. The second group includes countries with weak and medium export specialization, such as Cyprus, 
Greece, Malta, Portugal, and Latvia. During the crisis, the majority of Euro Area countries showed a marginal improvement of TBI index values (see Table 5). Specifically, the index improved in $90.5 \%$ of Greek sectors, $87.3 \%$ of the Latvian sectors, $85.7 \%$ of Portuguese sectors, and $76.26 \%$ of the Lithuanian sectors.

Table 4: Distribution of the net-export sectors (1995-16) (shares in total sectors)

\begin{tabular}{lllll}
\hline & \multicolumn{1}{c}{$\begin{array}{c}\text { All sectors } \\
(\mathbf{2})\end{array}$} & \multicolumn{1}{c}{$\begin{array}{c}\text { Agricultural } \\
\text { Products } \\
\mathbf{( 3 )}\end{array}$} & $\begin{array}{c}\text { Mineral fuels } \\
\text { and Raw } \\
\text { materials } \\
\mathbf{( 4 )}\end{array}$ & $\begin{array}{c}\text { Industrial } \\
\text { products } \\
\mathbf{( 5 )}\end{array}$ \\
\hline Austria & 33.33 & 6.35 & 3.17 & 23.81 \\
Belgium & 49.21 & 12.70 & 6.35 & 30.16 \\
Cyprus & 9.52 & 3.17 & 6.35 & 0.00 \\
Estonia & 25.40 & 4.76 & 7.94 & 12.70 \\
Finland & 36.51 & 3.17 & 6.35 & 26.98 \\
France & 38.10 & 11.11 & 6.35 & 20.63 \\
Germany & 58.73 & 11.11 & 4.76 & 42.86 \\
Greece & 11.11 & 6.35 & 3.17 & 1.59 \\
Ireland & 31.75 & 11.11 & 4.76 & 15.87 \\
Italy & 39.68 & 6.35 & 0.00 & 33.33 \\
Latvia & 20.63 & 3.17 & 7.94 & 9.52 \\
Lithuania & 23.81 & 7.94 & 7.94 & 7.94 \\
Malta & 11.11 & 1.59 & 3.17 & 6.35 \\
Netherlands & 58.73 & 19.05 & 4.76 & 34.92 \\
Portugal & 17.46 & 3.17 & 3.17 & 11.11 \\
Slovakia & 33.33 & 6.35 & 4.76 & 22.22 \\
Slovenia & 34.92 & 3.17 & 4.76 & 26.98 \\
Spain & 26.98 & 6.35 & 4.76 & 15.87 \\
\hline Colum & & & & \\
\hline
\end{tabular}

Note: Column 2 contains the share of net export sectors in the total sectors for the period 1995-2016. Columns 3-6 contain the share of net-export sectors in each product group (Agricultural, Mineral fuels and Raw materials, and Industrial). Source: Authors' calculations based on Comtrade.

Table 5: Evolution of net-exports between 2000-08 and 2009-14

\begin{tabular}{ccccccccc}
\hline AT & BE & CY & DE & EE & ES & FI & FR & GR \\
\hline 60.32 & 53.97 & 60.32 & 55.56 & 76.19 & 73.02 & 44.44 & 33.33 & 90.48 \\
\hline IE & IT & LT & LV & MT & NL & PT & SK & SI \\
\hline 53.97 & 65.08 & 76.29 & 87.3 & 46.03 & 61.91 & 85.71 & 61.91 & 66.67 \\
\hline
\end{tabular}

Note: Row 2 and 4 contains the share of net-exports sectors in the total sectors that showed even a marginal improvement on the TBI index in the period 2009-14 compared with the 2000-08 period. Source: Authors' calculations based on Comtrade.

\subsection{Stability of export specialization}

In this section, we present our results or the degree of stability of export specialization in the Euro Area. We test whether $\hat{\beta}$-values are significantly different from zero; this assumption was rejected for all countries. Thus, the evolution of the export specialization models in the Euro Area countries cannot be attributed to chance. Table 6 shows that in the Netherlands Belgium, Spain, Austria, Ireland, Portugal, Slovakia, Slovenia, Latvia, and Cyprus we have increased export specialization, while in the other countries there is a tendency to decrease it. Moreover, we observe that in countries where the regression result is small (i.e. high value of $\hat{\beta}$ ) and the mobility index is small (i.e. high value of $\hat{R}$ ) there is a very stable export specialization patterns. 
These results hold for the three selected time periods [(i) 2000-08 and 2009-14, (ii) 2000-08 and 2008-14, and (iii) 2000-09 and 2009-14].

Table 6: Examination of the degree of stability of export specialization patterns in Euro Area countries, between (i) 2000-8 and 2009-14, (ii) 2000-08 and 2008-14, and (iii) 2000-09 and 2009-14.

(i)

(ii)

(iii)

\begin{tabular}{l|cccc|cccc|cccc}
\hline \multicolumn{1}{l}{} & & & & $\hat{\beta} / \hat{\beta}$ & & & & $\hat{\beta} / \hat{\beta}$ & & & & $\hat{\beta} / \hat{\beta}$ \\
Countries & $\hat{\alpha}$ & $\hat{\beta}$ & $\hat{R}$ & $\hat{R}$ & $\hat{\alpha}$ & $\hat{\beta}$ & $\hat{R}$ & $\hat{R}$ & $\hat{\alpha}$ & $\hat{\beta}$ & $\hat{R}$ & $\hat{R}$ \\
\hline Germany & -0.011 & $0.894^{* *}$ & 0.937 & 0.956 & -0.011 & $0.893^{*}$ & 0.941 & 0.948 & -0.011 & $0.912^{*}$ & 0.943 & 0.967 \\
Netherlands & 0.027 & $0.967^{* *}$ & 0.953 & 1.015 & 0.029 & $0.971^{*}$ & 0.962 & 1.009 & 0.02 & $0.973^{*}$ & 0.966 & 1.007 \\
France & -0.027 & $0.934^{* *}$ & 0.953 & 0.981 & -0.024 & $0.938^{*}$ & 0.952 & 0.985 & -0.027 & $0.94^{*}$ & 0.948 & 0.991 \\
Italy & 0.011 & $0.914^{* *}$ & 0.961 & 0.951 & 0.009 & $0.919^{*}$ & 0.966 & 0.951 & 0.009 & $0.926^{*}$ & 0.966 & 0.958 \\
Belgium & -0.036 & $0.967^{* *}$ & 0.941 & 1.027 & -0.033 & $0.972^{*}$ & 0.960 & 1.012 & -0.035 & $0.971^{*}$ & 0.958 & 1.014 \\
Spain & -0.018 & $0.964^{* *}$ & 0.835 & 1.155 & -0.015 & $0.967^{*}$ & 0.908 & 1.064 & -0.018 & $0.985^{*}$ & 0.912 & 1.08 \\
Austria & 0.004 & $0.952^{*}$ & 0.909 & 1.046 & 0.002 & $0.954^{*}$ & 0.920 & 1.036 & 0.001 & $0.966^{*}$ & 0.919 & 1.05 \\
Ireland & -0.002 & $0.980^{* *}$ & 0.915 & 1.072 & -0.002 & $0.991^{*}$ & 0.970 & 1.021 & -0.002 & $0.997^{*}$ & 0.974 & 1.023 \\
Finland & 0.001 & $0.921^{* *}$ & 0.965 & 0.955 & 0.002 & $0.933^{*}$ & 0.957 & 0.974 & 0.006 & $0.937^{*}$ & 0.948 & 0.987 \\
Portugal & 0.058 & $0.987^{* *}$ & 0.919 & 1.073 & 0.052 & $0.993^{*}$ & 0.929 & 1.068 & 0.054 & $0.997^{*}$ & 0.933 & 1.068 \\
Greece & -0.059 & $0.917^{* *}$ & 0.936 & 0.979 & -0.053 & $0.923^{*}$ & 0.936 & 0.985 & -0.058 & $0.932^{*}$ & 0.937 & 0.995 \\
Slovakia & -0.035 & $0.899^{* *}$ & 0.810 & 1.109 & -0.042 & $0.924^{*}$ & 0.844 & 1.094 & -0.031 & $0.934^{*}$ & 0.84 & 1.111 \\
Slovenia & -0.047 & $-0.426^{*}$ & 0.335 & 1.273 & -0.039 & $-0.236^{* *}$ & 0.223 & 1.058 & -0.041 & $-0.336^{* *}$ & 0.227 & 1.48 \\
Estonia & 0.017 & $0.821^{* *}$ & 0.869 & 0.944 & 0.016 & $0.836^{*}$ & 0.879 & 0.951 & 0.015 & $0.854^{*}$ & 0.892 & 0.957 \\
Latvia & 0.078 & $0.852^{* *}$ & 0.771 & 1.103 & 0.077 & $0.87^{*}$ & 0.799 & 1.088 & 0.07 & $0.897^{*}$ & 0.81 & 1.107 \\
Cyprus & -0.020 & $0.910^{* *}$ & 0.779 & 1.169 & -0.019 & $0.922^{*}$ & 0.857 & 1.075 & -0.015 & $0.940^{*}$ & 0.865 & 1.086 \\
\hline
\end{tabular}

Note: $*, * *$ indicate significantly different from zero at the $5 \%, 1 \%$ levels, respectively.

\section{Empirical investigation of the relationship between export specialization and comparative advantages}

\subsection{Empirical Methodology}

In this section, we examine the relationship between export specialization and comparative advantages. Our econometric analysis uses annual data on 18 Euro Area economies from 1995 to $2016(T=22)$. The variables used in the empirical analysis are the TBI and RSCA indices. We conduct panel tests using 63 two-digit sectors for Austria, Belgium, Germany, Finland, France, Italy, the Netherlands, Portugal, Slovenia, and Spain; 62 sectors for Greece, Ireland, Lithuania, Latvia, and Slovakia; 61 sectors for Estonia; 59 sectors for Cyprus; and 52 sectors for Malta.

The structure of our empirical methodology is as follows. The first step is to test the integration properties of the variables using panel unit root tests. The second step is to test whether there is a long run relationship between the variables using panel cointegration tests. Then, if the variables are cointegrated, the long-run coefficients are estimated. In the third step, we employ Panel Granger tests to investigate the direction of relationship between the variables. 


\section{Cross-sectional dependence}

To test for cross sectional dependence in our data, we used Pesaran's CD test (2004). Pesaran (2004) developed an error cross-sectional dependence test that is based on the average of pairwise correlation coefficients of the Ordinary least square (OLS) residuals from the individual regressions in the panel. The $\mathrm{CD}$ test statistic is asymptotically standard normal, under the null hypothesis of cross-sectional independence. Table 7 reports the $\mathrm{CD}$ tests and the average correlation coefficients. The results of CD test reject the null hypothesis of no cross-sectional dependence in variables.

Table 7. CD tests

\begin{tabular}{|c|c|c|c|c|c|c|}
\hline & & $\begin{array}{r}\text { CD- } \\
\text { statistic } \\
\end{array}$ & $\begin{array}{r}\text { Abs. values corr. } \\
\text { Coefficient }\end{array}$ & & $\begin{array}{r}\text { CD- } \\
\text { statistic } \\
\end{array}$ & $\begin{array}{r}\text { Abs. values corr. } \\
\text { Coefficient }\end{array}$ \\
\hline \multirow[b]{2}{*}{ Austria } & RSCA & $17.45^{* * *}$ & 0.206 & \multirow[b]{2}{*}{ Italy } & $20.73 * * *$ & 0.213 \\
\hline & TBI & $3.55 * * *$ & 0.200 & & $19.41 * * *$ & 0.235 \\
\hline \multirow[b]{2}{*}{ Belgium } & RSCA & $20.59 * * *$ & 0.247 & \multirow[b]{2}{*}{ Latvia } & $8.57 * * *$ & 0.204 \\
\hline & TBI & $8.64 * * *$ & 0.210 & & $23.05 * * *$ & 0.227 \\
\hline \multirow{2}{*}{ Cyprus } & RSCA & $13.89 * * *$ & 0.206 & \multirow[b]{2}{*}{ Lithuania } & $10.73 * * *$ & 0.210 \\
\hline & TBI & $4.50 * * *$ & 0.182 & & $16.62 * * *$ & 0.226 \\
\hline \multirow{2}{*}{ Estonia } & RSCA & $10.19^{* * *}$ & 0.203 & \multirow{2}{*}{ Malta } & $17.19 * * *$ & 0.216 \\
\hline & TBI & $8.02 * * *$ & 0.194 & & $4.24 * * *$ & 0.190 \\
\hline \multirow{2}{*}{ Finland } & RSCA & $14.74 * * *$ & 0.207 & \multirow{2}{*}{ Netherlands } & $35.27 * * *$ & 0.282 \\
\hline & TBI & $7.04 * * *$ & 0.201 & & $11.95 * * *$ & 0.206 \\
\hline \multirow{2}{*}{ France } & RSCA & $5.62 * * *$ & 0.191 & \multirow{2}{*}{ Portugal } & $34.97 * * *$ & 0.277 \\
\hline & TBI & $9.9 * * *$ & 0.199 & & $16.98 * * *$ & 0.226 \\
\hline \multirow{2}{*}{ Germany } & RSCA & $34.18 * * *$ & 0.250 & \multirow{2}{*}{ Slovakia } & $20.37 * * *$ & 0.237 \\
\hline & TBI & $17.27 * * *$ & 0.220 & & $9.42 * * *$ & 0.196 \\
\hline \multirow{2}{*}{ Greece } & RSCA & $16.4 * * *$ & 0.208 & \multirow{2}{*}{ Slovenia } & $2.79 * * *$ & 0.200 \\
\hline & TBI & $17.96 * * *$ & 0.203 & & $8.23 * * *$ & 0.191 \\
\hline \multirow{2}{*}{ Ireland } & RSCA & $29.20 * * *$ & 0.251 & \multirow{2}{*}{ Spain } & $13.97 * * *$ & 0.205 \\
\hline & TBI & $6.66 * * *$ & 0.195 & & $27.83^{* * * *}$ & 0.231 \\
\hline
\end{tabular}

$*, * *$ and $* * *$ statistical significance at the $10 \%, 5 \%$ and $1 \%$ levels, respectively.

\section{Testing for integration}

To test the stationarity properties of the data, we use first and second generation panel unit root tests (PURTs). The first generation PURTs assume that the individual time series in the panel are cross-sectionally independently distributed. The test of LLC (Levin, Lin and Chu, 2002) and the IPS test (Im, Pesaran, and Shin, 2003) are first- generation PURTs . These tests have non-stationarity as the null hypothesis. The results of the PURTs for each variable are shown in Table 8 . We reject the null hypothesis for all variables in their first differences.

In contrast, the second-generation PURTs allow for cross-sectional dependence in the data. We use the CIPS (cross-sectionally augmented IPS) test that has been suggested by Pesaran (2007). The CIPS test augments the standard DF (or ADF) regressions with the crosssectional averages of lagged levels and first-differences of the individual series in the panel to solve the cross-dependence problem. The null hypothesis of CIPS test is non-stationarity. The results of CIPS test for lag orders $(p=0,1,2)$, (Table 9) indicate that the variables in first differences are stationary. 
Table 8. The IPS and LLC Panel Unit Root Tests

\begin{tabular}{|c|c|c|c|c|c|c|c|c|c|c|}
\hline & & \multicolumn{2}{|c|}{ RSCA } & \multicolumn{2}{|c|}{ TBI } & & \multicolumn{2}{|c|}{ RSCA } & \multicolumn{2}{|c|}{ TBI } \\
\hline & FD & Intercept & $\begin{array}{l}\text { Intercept } \\
\text { and trend }\end{array}$ & Intercept & $\begin{array}{l}\text { Intercept } \\
\text { and trend }\end{array}$ & & Intercept & $\begin{array}{l}\text { Intercept } \\
\text { and trend }\end{array}$ & Intercept & $\begin{array}{l}\text { Intercept } \\
\text { and trend }\end{array}$ \\
\hline \multirow{2}{*}{ Austria } & LLC & $-26.927 * * *$ & $-23.130^{* * *}$ & $-26.786^{* * *}$ & $-21.705^{* * * *}$ & \multirow{2}{*}{ Italy } & $-14.39 * * *$ & $-15.698 * * *$ & $-24.199 * * *$ & $-20.097 * * *$ \\
\hline & IPS & $-27.220 * * *$ & $-24.538 * * *$ & $-25.039 * * *$ & $-23.095 * * *$ & & $-22.968 * * *$ & $-18.879 * * *$ & $-22.51 * * *$ & $-21.528^{* * * *}$ \\
\hline \multirow{2}{*}{ Belgium } & LLC & $-22.882 * * *$ & $-23.595^{* * *}$ & $-28.639^{* * *}$ & $-22.189^{* * * *}$ & \multirow{2}{*}{ Latvia } & $-27.656^{* * *}$ & $-24.729 * * *$ & $-26.741^{* * *}$ & $-22.062 * * *$ \\
\hline & IPS & $-20.208^{* * *}$ & $-18.947 * * *$ & $-25.161^{* * * *}$ & $-19.935^{* * * *}$ & & $-26.231 * * *$ & $-23.087 * * *$ & $-25.448^{* * * *}$ & $-21.339 * * *$ \\
\hline \multirow{2}{*}{ Cyprus } & LLC & $-27.095^{* * *}$ & $-23.17 * * *$ & $-23.417^{* * * *}$ & $-19.249^{* * *}$ & \multirow{2}{*}{ Lithuania } & $-25.016^{* * *}$ & $-21.9 * * *$ & $-24.726^{* * *}$ & $-21.191 * * *$ \\
\hline & IPS & $-27.341 * * *$ & $-24.278 * * *$ & $-24.024 * * *$ & $-20.971 * * *$ & & $-22.956 * * *$ & $-20.245 * * *$ & $-22.405^{* * * *}$ & $-18.681^{* * * *}$ \\
\hline \multirow{2}{*}{ Estonia } & LLC & $-26.808^{* * *}$ & $-23.406^{* * *}$ & $-25.433^{* * *}$ & $-21.48^{* * *}$ & \multirow{2}{*}{ Malta } & $-25.397 * * *$ & $-19.987 * * *$ & $-24.437 * * *$ & $-22.046^{* * *}$ \\
\hline & IPS & $-24.527 * * *$ & $-21.642 * * *$ & $-24.838 * * *$ & $-22.165 * * *$ & & $-24.002 * * *$ & $-18.505 * * *$ & $-24.385^{* * *}$ & $-19.458 * * *$ \\
\hline \multirow{2}{*}{ Finland } & LLC & $-27.527 * * *$ & $-22.58 * * *$ & $-28.227 * * *$ & $-23.279 * * *$ & \multirow{2}{*}{ Netherlands } & $-25.335 * * *$ & $-20.646 * * *$ & $-26.917 * * *$ & $-20.737 * * *$ \\
\hline & IPS & $-26.76^{* * * *}$ & $-22.482 * * *$ & $-26.23 * * *$ & $-21.477 * * *$ & & $-25.153 * * *$ & $-20.89 * * *$ & $-26.297 * * *$ & $-20.818^{* * *}$ \\
\hline \multirow{2}{*}{ France } & LLC & $-28.414 * * *$ & $-26.201 * * *$ & $-28.414 * * *$ & $-25.393^{* * *}$ & \multirow{2}{*}{ Portugal } & $-29.991 * * *$ & $-25.262 * * *$ & $-22.787 * * *$ & $-18.676^{* * *}$ \\
\hline & IPS & $-28.816^{* * * *}$ & $-25.032 * * *$ & $-26.238 * * *$ & $-22.489 * * *$ & & $-27.559 * * *$ & $-23.132 * * *$ & $-22.484 * * *$ & $-18.399 * * *$ \\
\hline \multirow{2}{*}{ Germany } & LLC & $-27.854 * * *$ & $-22.08 * * *$ & $-28.03^{* * *}$ & $-20.414^{* * * *}$ & \multirow{2}{*}{ Slovakia } & $-25.777 * * *$ & $-21.616 * * *$ & $-29.34 * * *$ & $-25.542 * * *$ \\
\hline & IPS & $-27.858^{* * *}$ & $-24.282 * * *$ & $-28.372 * * *$ & $-24.05^{* * *}$ & & $-26.551 * * *$ & $-21.811 * * *$ & $-28.432 * * *$ & $-23.449 * * *$ \\
\hline \multirow{2}{*}{ Greece } & LLC & $-27.834 * * *$ & $-23.567 * * * *$ & $-27.746^{* * *}$ & $-21.766^{* * * *}$ & \multirow{2}{*}{ Slovenia } & $-19.656 * * *$ & $-16.975 * * *$ & $-22.157 * * *$ & $-18.146 * * *$ \\
\hline & IPS & $-27.551 * * *$ & $-22.882 * * *$ & $-27.374 * * *$ & $-21.948 * * *$ & & $-20.474 * * *$ & $-17.58 * * *$ & $-23.296 * * *$ & $-20.485^{* * * *}$ \\
\hline \multirow{2}{*}{ Ireland } & LLC & $-26.126^{* * *}$ & $-18.783 * * *$ & $-26.153 * * *$ & $-22.441 * * *$ & \multirow{2}{*}{ Spain } & $-28.414 * * *$ & $-26.201 * * *$ & $-28.414 * * *$ & $-25.393 * * *$ \\
\hline & IPS & $-25.598^{* * * *}$ & $-19.427 * * * *$ & $-24.271^{* * * *}$ & $-20.49 * * *$ & & $-28.816^{* * *}$ & $-25.032 * * *$ & $-26.238^{* * * *}$ & $-22.489 * * *$ \\
\hline
\end{tabular}

Notes: $* * *$ indicates rejection of the null hypothesis of $\mathrm{I}(1)$ at the $1 \%$ level of significance. Lags are selected according to the Schwarz Bayesian Criterion (SBC). FD: First Differences. LLC: Levin, Lin and Chu (2002) test statistic. IPS: Im, Pesaran, and Shin (2003) test statistic.

Table 9. The CIPS Panel Unit Root Tests

\begin{tabular}{|c|c|c|c|c|c|c|c|c|c|c|}
\hline & \multicolumn{3}{|c|}{ RSCA } & \multicolumn{2}{|c|}{ TBI } & & \multicolumn{2}{|c|}{ RSCA } & \multicolumn{2}{|c|}{ TBI } \\
\hline & FD & Intercept & $\begin{array}{l}\text { Intercept } \\
\text { and trend }\end{array}$ & Intercept & $\begin{array}{l}\text { Intercept } \\
\text { and trend }\end{array}$ & & Intercept & $\begin{array}{l}\text { Intercept } \\
\text { and trend }\end{array}$ & Intercept & $\begin{array}{l}\text { Intercept } \\
\text { and trend }\end{array}$ \\
\hline \multirow{3}{*}{ Austria } & $\mathrm{p}=0$ & $-4.407 * * *$ & $-4.655^{* * *}$ & $-4.625^{* * *}$ & $-4.812 * * *$ & \multirow{3}{*}{ Italy } & $-3.652 * * *$ & $-3.405 * * *$ & $-3.680 * * *$ & $-3.753 * * *$ \\
\hline & $\mathrm{p}=1$ & $-3.236 * * *$ & $-3.462 * * *$ & $-.121 * * *$ & $-3.339 * * *$ & & $-2.334 * * *$ & $-2.829^{*}$ & $-2.824 * * *$ & $-2.638^{*}$ \\
\hline & $\mathrm{p}=2$ & $-2.078^{* *}$ & -2.268 & $-2.018^{* *}$ & -2.400 & & $-2.376^{* * * *}$ & -2.345 & $-2.204 * * *$ & -1.933 \\
\hline \multirow{3}{*}{ Belgium } & $\mathrm{p}=0$ & $-2.573 * *$ & $-2.496^{*}$ & $-3.512 * * *$ & $-3.523 * * *$ & \multirow{3}{*}{ Latvia } & $-4.023 * * *$ & $-4.098 * * *$ & $-4.327 * * *$ & $-4.444 * * *$ \\
\hline & $\mathrm{p}=1$ & $-2.491^{*}$ & $-2.450^{*}$ & $-2.902 * * *$ & $-2.847 * * *$ & & $-3.527 * * *$ & $-3.634 * * *$ & $-3.147 * * *$ & $-3.198 * * *$ \\
\hline & $\mathrm{p}=2$ & -1.89 & -2.011 & $-1.897 *$ & -1.997 & & $-2.687 * * *$ & $-2.801 * * *$ & $-2.548 * * *$ & $-2.580 * *$ \\
\hline \multirow{3}{*}{ Cyprus } & $\mathrm{p}=0$ & $-2.409 * *$ & $-2.615^{*}$ & $-2.599 * *$ & $-2.858 * *$ & \multirow{3}{*}{ Lithuania } & $-4.023 * * *$ & $-4.098 * * *$ & $-4.327 * * *$ & $-4.444 * * *$ \\
\hline & $\mathrm{p}=1$ & $-2.308^{*}$ & 2.271 & $-2.403^{*}$ & -2.329 & & $-3.527 * * *$ & $-3.634 * * *$ & $-3.147 * * *$ & $-3.198 * * *$ \\
\hline & $\mathrm{p}=2$ & $-2.242 * * *$ & $-2.482^{*}$ & $-2.38 * * *$ & -2.373 & & $-2.687 * * *$ & $-2.801 * * *$ & $-2.548 * * *$ & $-2.580 * *$ \\
\hline \multirow{3}{*}{ Estonia } & $\mathrm{p}=0$ & $-4.297 * * *$ & $-4.367 * * *$ & $-4.623 * * *$ & $4.711 * * *$ & \multirow{3}{*}{ Malta } & $-4.562 * * *$ & $-4.665 * * *$ & $-4.834 * * *$ & $-4.878 * * *$ \\
\hline & $\mathrm{p}=1$ & $-3.252 * * *$ & $-3.357^{* * * *}$ & $-3.418 * * *$ & $-3.481 * * *$ & & $-2.998 * * *$ & $-3.13 * * *$ & $-3.29 * * *$ & $-3.352 * * *$ \\
\hline & $\mathrm{p}=2$ & $-2.302 * * *$ & -2.306 & $-2.477 * * *$ & $-2.633 * * *$ & & $-2.187 * *$ & -2.324 & $-2.351 * * *$ & -2.466 \\
\hline \multirow{3}{*}{ Finland } & $\mathrm{p}=0$ & $-4.416^{* * * *}$ & -4.557 *** & $-4.371 * * *$ & $-4.501 * * *$ & \multirow{3}{*}{ Netherlands } & $-2.681^{* *}$ & $-2.823 * * *$ & $-2.288^{*}$ & $-2.697 * *$ \\
\hline & $\mathrm{p}=1$ & $-3.126^{* * *}$ & $-3.362 * * *$ & $-3.083 * * *$ & $-3.219 * * *$ & & 2.463 & -2.623 & 2.157 & -2.497 \\
\hline & $\mathrm{p}=2$ & $-2.242 * * *$ & $-2.475^{* * * *}$ & $-2.173 * * *$ & $-2.195 * * *$ & & $-2.492 * * *$ & -2.314 & $-2.78 * * *$ & $-2.936 * * *$ \\
\hline \multirow{3}{*}{ France } & $\mathrm{p}=0$ & $-4.581 * * *$ & $-4.706^{* * * *}$ & $-4.539 * * *$ & $-4.648 * * *$ & \multirow{3}{*}{ Portugal } & $-4.07 * * *$ & $-4.11 * * *$ & $-4.403 * * *$ & $-4.611 * * *$ \\
\hline & $\mathrm{p}=1$ & $-3.486^{* * *}$ & $-3.682^{* * * *}$ & $-3.502 * * *$ & $-3.654 * * *$ & & $-2.925^{* * * *}$ & $-3.079 * * *$ & $-3.112 * * *$ & $-3.54 * * *$ \\
\hline & $\mathrm{p}=2$ & $-2.283^{* * *}$ & $-2.499^{*}$ & $-2.522 * * *$ & $-2.798 * * *$ & & $-2.176^{* * * *}$ & -2.238 & $-2.286^{* * *}$ & $-2.71 * * *$ \\
\hline \multirow{3}{*}{ Germany } & $\mathrm{p}=0$ & $-4.430 * * *$ & $-4.512^{* * *}$ & $-4.747 * * *$ & $-4.015 * * *$ & \multirow{3}{*}{ Slovakia } & $-4.555^{* * * *}$ & $-4.716^{* * *}$ & $-4.066^{* * *}$ & $-4.154 * * *$ \\
\hline & $\mathrm{p}=1$ & $-2.897 * * *$ & $-3.014 * * *$ & $-3.609 * * *$ & $-3.938 * * *$ & & $-3.203^{* * * *}$ & $-3.294 * * *$ & $-3.102 * * *$ & $-3.17 * * *$ \\
\hline & $\mathrm{p}=2$ & $-2.109 * * *$ & -2.292 & $-2.399 * * *$ & $-2.578 * *$ & & $-2.148^{* * * *}$ & -2.176 & $-2.343^{* * *}$ & $-2.466^{*}$ \\
\hline \multirow{3}{*}{ Greece } & $\mathrm{p}=0$ & $-4.689 * * *$ & $-4.807^{* * * *}$ & $-4.609 * * *$ & $-4.76 * * *$ & \multirow{3}{*}{ Slovenia } & $-4.747 * * *$ & $-4.015^{* * *}$ & $-4.430 * * *$ & $-4.512 * * *$ \\
\hline & $\mathrm{p}=1$ & $-3.486^{* * *} *$ & $-3.531 * * *$ & $-3.526^{* * *} *$ & $-3.731 * * *$ & & $-3.609 * * *$ & $-3.938 * * *$ & $-2.897 * * *$ & $-3.014 * * *$ \\
\hline & $\mathrm{p}=2$ & $-2.607 * * *$ & -2.424 & $-2.661 * * *$ & $-2.756 * * *$ & & $-2.399 * * *$ & $-2.578 * *$ & $-2.109 * * *$ & -2.292 \\
\hline \multirow{3}{*}{ Ireland } & $\mathrm{p}=0$ & $-4.496 * * *$ & $-4.624 * * *$ & $-2.349 * *$ & $-4.872 * * *$ & \multirow{3}{*}{ Spain } & $-4.679 * * *$ & $-4.729 * * *$ & $-4.845^{* * *}$ & $-4.934 * * *$ \\
\hline & $\mathrm{p}=1$ & $-3.154 * * *$ & $-3.240^{* * *}$ & $-2.322 * *$ & $-3.228 * * *$ & & $-3.685^{* * *}$ & $-3.821 * * *$ & $-3.426 * * *$ & $-3.545 * * *$ \\
\hline & $\mathrm{p}=2$ & $-2.434 * * *$ & $-2.597^{* *}$ & $-2.404 * *$ & $-2.432 * *$ & & $-2.36^{* * * *}$ & $-2.484 *$ & $-2.427 * * *$ & $-2.511 *$ \\
\hline
\end{tabular}

Notes: $* *$ and $* * *$ indicate rejection of the null hypothesis at the $5 \%$ and $1 \%$ significant levels, respectively. FD: First Differences. Lags are selected according to the Schwarz Bayesian Criterion (SBC). 


\section{Testing for cointegration}

We use panel cointegration tests to investigate whether there is a cointegrating relationship between the variables. Westerlund (2007) has developed the second-generation panel cointegration tests. These tests have better size and power than residual-based panel cointegration tests. This procedure is proposed to handle cross-sectional dependence through bootstrapping. Four tests are designed to test the null hypothesis of no cointegration by examining whether the error correction term in a conditional error correction model is equal to zero. Thus, if the null hypothesis of no error correction is rejected, then the null hypothesis of no cointegration is also rejected. All tests are asymptotically normally distributed. Each test accommodates individual-specific short-run dynamics, including serially correlated error terms and non-strictly exogenous regressors, individual specific intercept and trend terms, as well as individual-specific slope parameters. The two panel tests $\left(P_{t}-\right.$ stat and $P_{a}-$ stat $)$ have no cointegration as their null hypothesis for the panel as a whole. The Group Mean Tests ( $G_{t}-$ stat and $G_{\alpha}-$ stat) have as null hypothesis that of no cointegration for all crosssectional units against the alternative that there is cointegration for at least one unit. The results of the Westerlund (2007) panel cointegration test are reported in Table 10. The results provide sufficient evidence in favor of cointegration for all countries (i.e. the null hypothesis is rejected in most of the statistics). Therefore, the empirical results confirm the existence of a long run equilibrium relationship between comparative advantages and export specialization for all the examined countries.

Table 10. Westerlund's (2007) panel cointegration tests

\begin{tabular}{|c|c|c|c|c|}
\hline Statistics & $G_{T}$ & $P_{a}$ & $P_{T}$ & $G_{\alpha}$ \\
\hline Austria & $-3.6242 * *$ & $-11.435 * * *$ & $-12.542 *$ & $-14.421 * *$ \\
\hline Belgium & -2.864 & $-10.776 * * *$ & $-16.195 * *$ & $-18.524 * *$ \\
\hline Cyprus & 2.252 & $-10.293^{*}$ & $-16.101 *$ & $-14.594 *$ \\
\hline Estonia & $-4.531 * * *$ & $-16.404 * * *$ & $-18.122 * * *$ & $-20.933 * * *$ \\
\hline Finland & $-2.007 * *$ & $-6.551 * *$ & -14.483 & $-12.642 *$ \\
\hline France & $-4.368 * *$ & $-12.254 * * *$ & $-18.404 * * *$ & $-14.561 * * *$ \\
\hline Germany & -2.463 & $-9.868^{*}$ & $-19.973 * * *$ & $-14.641 * *$ \\
\hline Greece & -2.029 & $-10.341^{*}$ & $-13.622 *$ & $-12.878 *$ \\
\hline Ireland & -2.675 & $-14.927 *$ & $-19.302 * *$ & $-16.308 * *$ \\
\hline Italy & $-4.721 * * *$ & $-16.98 * *$ & $-22.974 * * *$ & $-18.119 * * *$ \\
\hline Latvia & -2.082 & $-8.567 * *$ & $-12.023^{* *}$ & $-10.449 *$ \\
\hline Lithuania & $-2.540 *$ & $-9.381 *$ & $-18.950 *$ & $-8.411 *$ \\
\hline Malta & -2.278 & $-10.203 * * *$ & $-16.726 * * *$ & $-10.784 * * *$ \\
\hline Netherlands & $-3.568 * *$ & $-10.745 * * *$ & $-18.913 * * *$ & $-16.346 * * *$ \\
\hline Portugal & $-2.932 *$ & $-8.908 * *$ & $-16.829 * * *$ & $-10.36^{*}$ \\
\hline Slovakia & $-3.751 * *$ & $-14.306 * *$ & $-18.291 * * *$ & $-16.358 * * *$ \\
\hline Slovenia & $-3.862 * *$ & $-14.407 * * *$ & $-18.867 * * *$ & $-20.293 * * *$ \\
\hline Spain & $-3.180 * *$ & -14.576 & $-18.523 * * *$ & $-16.648 * * *$ \\
\hline
\end{tabular}

$*, * *$ and $* * *$ indicate rejection of the null hypothesis of no cointegration at the $10 \%, 5 \%$ and $1 \%$ significant levels, respectively. Bootstrap replication of 600 is used to correct for cross-sectional dependence. 


\section{Estimation}

Having confirmed the existence of a long run relationship between comparative advantages and export specialization, we estimate this cointegrating relationship for each country. We first implement the FMOLS method for heterogeneous cointegrated panels. This method produces asymptotically unbiased estimators, and has no nuisance parameters in its asymptotic normal distribution for its estimator ${ }^{7}$. To eliminate the problem of bias due to the endogeneity of the regressors, Pedroni developed the group-means FMOLS estimator, by incorporating the Phillips and Hansen (1990) semi-parametric correction into the OLS estimator. The technique accounts fully for heterogeneity in short-run dynamics as well as for fixed effects. For panels that exhibit common disturbances that are shared across individual members, Pedroni (2000) have noted that it will be convenient to capture this form of cross sectional dependence by the use of a common time dummy.

We use the CCEMG estimator because our variables are heterogeneous and crosssectionally correlated. The presence of cross-sectional dependence means that unobserved factors in the error term could be correlated with the explanatory variables. The CCE approach corrects cross-sectional dependence of the error terms due to unobserved common factors. Neglecting such dependencies could lead to biased estimates and to spurious inference. In particular, this estimation approach permits the common effects to have differential impacts on individual units, while at the same time allows them to have an arbitrary degree of correlation among themselves as well as with the individual-specific regressors. The CCE estimator has the additional advantage that it can be computed by ordinary least squares applied to an auxiliary regression where the observed regressors are augmented by cross-sectional averages of the dependent variable and the individual specific regressors (Pesaran 2006). Finally, this estimator is shown to perform well in the case where the unobserved factors follow unit root processes (Kapetanios et. al (2011).

We also use the CCEPMG estimator. Chydik and Pesaran (2015) extend the CCE approach developed by Pesaran (2006) to dynamic heterogeneous panel data models with weakly exogenous regressors. They show that the CCE mean group estimator continues to be valid but the following two conditions must be satisfied to deal with the dynamics: a sufficient number of lags of cross section averages must be included in individual equations of the panel, and the number of cross section averages must be at least as large as the number of unobserved common factors. The estimated coefficients of the FMOLS, CCEMG, and CCEPMG estimators

\footnotetext{
7 It is well known that the standard panel OLS estimator is asymptotically biased and its distribution is dependent on nuisance parameters associated with the underlying dynamic processes.
} 
are presented in Table 11. The results indicate a positive and significant relationship between RSCA and TBI for all countries.

We also implement the Generalized Method of Moments GMM - System estimator (Arellano and Bover, 1995; and Blundell and Bond, 1998) to deal with the simultaneity and endogeneity issues. This method allows for controlling the potential sources of endogeneity which are inherent in the export specialization and comparative advantages relationship. The GMM procedure is appropriate for panel data that has a large number of sectors and a small time dimension. The regression equation has the following form:

$$
t b i_{i t}=\gamma t b i_{i, t-1}+\delta r s c a_{i t}+e_{i t}
$$

In order to solve the problem of correlation between the explanatory variable and the error term, we transform the regressors using first differences. Taking first difference, the unobserved sector-specific effects is removed. Thus, the basic advantage of this estimator is that it takes into account the potential correlation of explanatory variable with the error term. GMM-System combines one equation in first-difference form (where the endogenous variables are instrumented by their lagged levels) with an equation in levels, in which variables are instrumented by their own lagged first-differences. Equation (6) can be rewritten as follows:

$$
\Delta t b i_{i t}=\gamma \Delta t b i_{i, t-1}+\delta \Delta r s c a_{i t}+\Delta e_{i t}
$$

where $i$ and $t$ represent the sector and time period respectively, $\Delta$ is the first difference operator, $t b i_{i t}$ is the dependent variable and $t b i_{i, t-1}$ represent its lagged value, $r s c a_{i \mathrm{t}}$ is the explanatory variable, $e_{i t}$ is the error term that includes sector-specific and time-specific effects.

The estimation results of equation (7) are shown in Table 13. The Hansen test of overidentifying restrictions and the Arellano and Bond (1991) test for first and second order autocorrelation in the first-difference residuals are reported in Table 12. Results indicate that the instrument set can be considered valid and that the null hypothesis of no autocorrelation of second order can be accepted. These provide robust evidence that comparative advantages are a significant factor in boosting net export in the majority of EA countries. 
Table 11: Estimations results, 1995-2016

\begin{tabular}{|c|c|c|c|c|c|c|c|c|}
\hline \multirow{3}{*}{$\frac{\text { Country }}{\text { Austria }}$} & \multicolumn{2}{|c|}{$\begin{array}{c}\text { Panel FMOLS } \\
\text { estimator }\end{array}$} & \multicolumn{3}{|c|}{ Panel CCEMG estimator } & \multicolumn{3}{|c|}{ Panel CCEPMG estimator } \\
\hline & Coefficient & t-statistic & Coefficient & 95\% C.I. & & Coefficient & C.I. & \\
\hline & $0.730 * * *$ & 24.762 & $0.758 * * *(11.50)$ & {$[0.62$} & $0.87]$ & $0.416^{* *}(12.6)$ & {$[0.35$} & $0.48]$ \\
\hline Belgium & $0.514^{* * *}$ & 16.805 & $0.479 * * *(8.21)$ & {$[0.36$} & $0.59]$ & $0.36^{* *}(6.72)$ & {$[0.25$} & $0.46]$ \\
\hline Cyprus & $0.599 * * *$ & 25.593 & $0.579 * * *(9.23)$ & {$[0.45$} & $0.72]$ & $0.502 * *(11.62)$ & {$[0.41$} & $0.58]$ \\
\hline Estonia & $0.662 * * *$ & 21.976 & $0.861 * * *(8.12)$ & {$[0.65$} & 1.06] & $0.555 * *(11.56)$ & {$[0.45$} & $0.63]$ \\
\hline Finland & $0.902^{* * *}$ & 28.352 & $0.841 * * *(9.86)$ & {$[0.68$} & 1.12] & $1.02^{* *}(8.55)$ & {$[0.78$} & 1.25] \\
\hline France & $0.634^{* * *}$ & 17.775 & $0.631 * * *(11.95)$ & {$[0.52$} & $0.73]$ & $0.606 * *(10.83)$ & {$[0.42$} & $0.58]$ \\
\hline Germany & $0.686^{* * *}$ & 20.354 & $0.581 * * *(8.77)$ & {$[0.45$} & $0.71]$ & $0.446 * *(8.24)$ & {$[0.30$} & $0.50]$ \\
\hline Greece & $0.559^{* * *}$ & 10.254 & $0.718^{* * *}(9.45)$ & {$[0.68$} & $0.82]$ & $0.719 * *(12.45)$ & {$[0.60$} & $0.83]$ \\
\hline Ireland & $0.736^{* * *}$ & 19.852 & $1.026^{* * *}(11.92)$ & {$[0.97$} & 1.40] & $0.965 * *(12.01)$ & {$[0.80$} & 1.12] \\
\hline Italy & $0.802 * * *$ & 20.26 & $0.801 * * *(11.57)$ & {$[0.66$} & $0.93]$ & $0.864 * *(9.26)$ & {$[0.54$} & $0.82]$ \\
\hline Latvia & $0.829 * * *$ & 25.694 & $0.826^{* * * *}(11.03)$ & {$[0.67$} & $0.97]$ & $0.752 * *(4.54)$ & {$[0.28$} & $0.85]$ \\
\hline Lithuania & $0.786^{* * *}$ & 22.753 & $0.672 * * *(9.54)$ & {$[0.52$} & 0.81] & $0.62^{* *}(11.1)$ & {$[0.45$} & $0.64]$ \\
\hline Malta & $0.901 * * *$ & 21.837 & $1.002 * * *(8.22)$ & {$[0.76$} & 1.24] & $0.857 * *(8.07)$ & {$[0.64$} & $1.06]$ \\
\hline Netherlands & $0.548^{* * *}$ & 20.984 & $0.497 * * *(10.92)$ & {$[0.40$} & $0.58]$ & $0.491 * *(9.48)$ & {$[0.38$} & $0.59]$ \\
\hline Portugal & $0.484 * * *$ & 18.032 & $0.749^{* * *}(19.21)$ & {$[0.82$} & $0.67]$ & $0.683^{* *}(15.61)$ & {$[0.76$} & $0.59]$ \\
\hline Slovakia & $0.478 * * *$ & 15.035 & $0.69 * * *(14.37)$ & {$[0.59$} & $0.78]$ & $0.587 * *(12.57)$ & {$[0.49$} & 067] \\
\hline Slovenia & $0.702 * * *$ & 25.637 & $0.631 * * *(8.83)$ & {$[0.49$} & 0.77] & $0.466^{* *}(9.83)$ & {$[0.37$} & $0.56]$ \\
\hline Spain & $0.723 * * *$ & 15.709 & $0.801 * * *(11.14)$ & {$[0.66$} & 0.94] & $0.699 * *(13.99)$ & {$[0.60$} & $0.79]$ \\
\hline
\end{tabular}

$*$ and $* *$ indicate significance levels at the $5 \%$ and $1 \%$, respectively. t-values are in parentheses. Note:

Asymptotic distribution of $\mathrm{t}$-statistic is standard normal as $\mathrm{T}$ and $\mathrm{N}$ go to infinity. C.I.: confidence interval.

Table 12: Dynamic panel-data estimation, one-step system GMM

\begin{tabular}{|c|c|c|c|c|c|c|c|c|}
\hline Country & Coefficient & $\begin{array}{c}\text { Arellano- } \\
\text { Bond } \\
\text { AR(1) }\end{array}$ & $\begin{array}{c}\text { Arellano- } \\
\text { Bond } \\
\text { AR(2) }\end{array}$ & $\begin{array}{c}\text { Hansen } \\
\text { test } \\
\text { (p-values) }\end{array}$ & $\begin{array}{c}\text { Sargan } \\
\text { test } \\
\text { (p-value) }\end{array}$ & $\begin{array}{l}\text { Number of } \\
\text { Instruments }\end{array}$ & $\begin{array}{l}\text { Number } \\
\text { of Group }\end{array}$ & Obs. \\
\hline Austria & $0.848 * * *(0.019)$ & 0.000 & 0.681 & 0.365 & 0.000 & 40 & 63 & 1260 \\
\hline Belgium & $0.653 * * *(0.030)$ & 0.002 & 0.865 & 0.168 & 0.000 & 32 & 63 & 1008 \\
\hline Cyprus & $0.783 * * *(0.002)$ & 0.043 & 0.145 & 0.155 & 0.000 & 40 & 59 & 1180 \\
\hline Estonia & $0.867 * * *(0.025)$ & 0.003 & 0.174 & 0.119 & 0.023 & 40 & 61 & 1220 \\
\hline Finland & $0.792 * * *(0.021)$ & 0.036 & 0.834 & 0.107 & 0.000 & 40 & 63 & 1260 \\
\hline France & $0.47 * * *(0.026)$ & 0.011 & 0.527 & 0.134 & 0.000 & 40 & 63 & 1260 \\
\hline Germany & $0.771 * * *(0.025)$ & 0.016 & 0.437 & 0.325 & 0.000 & 40 & 63 & 1260 \\
\hline Greece & $0.451 * * *(0.027)$ & 0.000 & 0.202 & 0.129 & 0.000 & 40 & 62 & 1240 \\
\hline Ireland & $0.624 * * *(0.037)$ & 0.001 & 0.396 & 0.154 & 0.000 & 40 & 62 & 1240 \\
\hline Italy & $0.737 * * *(0.023)$ & 0.060 & 0.165 & 0.184 & 0.000 & 40 & 62 & 1240 \\
\hline Latvia & $0.804 * * *(0.024)$ & 0.155 & 0.001 & 0.289 & 0.000 & 40 & 62 & 1240 \\
\hline Lithuania & $1.004 * * *(0.028)$ & 0.006 & 0.895 & 0.459 & 0.000 & 40 & 62 & 1240 \\
\hline Malta & $1.124 * * *(0.039)$ & 0.013 & 0.369 & 0.256 & 0.000 & 40 & 52 & 1034 \\
\hline Netherlands & $0.896 * * *(0.032)$ & 0.001 & 0.11 & 0.106 & 0.000 & 40 & 62 & 1240 \\
\hline Portugal & $0.631 * * *(0.015)$ & 0.001 & 0.324 & 0.227 & 0.000 & 40 & 63 & 1260 \\
\hline Slovakia & $0.711^{* * *}(0.026)$ & 0.014 & 0.131 & 0.425 & 0.000 & 40 & 63 & 1260 \\
\hline Slovenia & $0.719 * * *(0.016)$ & 0.065 & 0.500 & 0.377 & 0.000 & 40 & 62 & 1240 \\
\hline Spain & $0.683 * * *(0.027)$ & 0.025 & 0.264 & 0.105 & 0.000 & 40 & 63 & 1260 \\
\hline
\end{tabular}

$*$, ** and $* * *$ indicate significance levels at the $10 \%, 5 \%$ and $1 \%$, respectively. 


\section{Testing for Granger Causality}

We conduct Granger causality tests we use the method proposed by Dumitrescu and Hurlin (2012) to detect the direction of causality between export specialization and CAs. The Dumitrescu-Hurlin approach takes into account the cross-sectional dependence among sectors, and allows heterogeneity of the regression model across individual units. The Dumitrescu-Hurlin panel Granger causality test is based on the individual Wald statistics of Granger non causality averaged across the cross-section units. This test uses the following model to test for Granger causality:

$$
y_{i, t}=\alpha_{i}+\sum_{k=1}^{K} \gamma_{i}^{(k)} y_{i, t-k}+\sum_{k=1}^{K} \beta_{i}^{(k)} x_{i, t-k}+\varepsilon_{i, t}
$$

where $\alpha_{i}$ denotes the individual effects, $K$ represents lag orders which is identical for all crosssectional units of the panel, and $\gamma_{i}^{(k)}$ and $\beta_{i}^{(k)}$ are group-specific parameters. The null hypothesis of the Dumitrescu-Hurlin panel Granger causality test is that no Granger causality exists for any unit of the panel, and the alternative is that there is Granger causality for at least one unit. The null and alternative hypotheses are defined as:

$$
\begin{aligned}
& H_{0}: \beta_{i}^{k}=0 \quad \forall \quad i=1, \ldots \ldots . N \\
& H_{1}:\left\{\begin{array}{l}
\beta_{i}=0 \quad \forall \quad i=1,2, \ldots \ldots \ldots . . N \\
\beta_{i}{ }_{i} \neq 0
\end{array} \quad \forall i=N+1, \ldots \ldots . . N\right.
\end{aligned}
$$

Table 13 shows the results of the Dumitrescu-Hurlin (2012) panel Granger non-causality test. We find that direct Granger causality runs from CAs to export specialization in Austria, Belgium, Cyprus, Estonia, Finland, France, Germany, Latvia, the Netherlands, Slovenia, and Spain. Moreover, the empirical evidence indicates bidirectional causality relationship in Ireland, Lithuania, Malta, and Slovakia. Finally, there is evidence that net exports Granger-cause CAs in Greece, Italy, and Portugal. In these countries, exports in sectors possessing CAs strongly

\begin{tabular}{|c|c|c|c|c|c|c|}
\hline & \multicolumn{3}{|c|}{$\begin{array}{l}H_{01} \text { : Comparative advantage does not } \\
\text { Granger cause Export specialization }\end{array}$} & \multicolumn{3}{|c|}{$\begin{array}{l}H_{02}: \text { Export specialization does not } \\
\text { Granger cause Comparative advantage }\end{array}$} \\
\hline & W stat & $Z$ stat & p-value & W stat & $Z$ stat & p-value \\
\hline Austria & $12.176^{* * * *}$ & $3.688^{* * * *}$ & 0.000 & 8.342 & 2.141 & 0.185 \\
\hline Belgium & $5.574 * *$ & $2.550^{* * *}$ & 0.010 & 4.987 & 1.599 & 0.109 \\
\hline Cyprus & $3.539 * * *$ & $3.510 * * *$ & 0.000 & 2.686 & 1.079 & 0.280 \\
\hline Estonia & $5.082^{* * *}$ & $3.089 * * *$ & 0.002 & 4.558 & 2.021 & 0.106 \\
\hline Finland & $6.822 * *$ & $2.471^{* *}$ & 0.013 & 5.918 & 1.141 & 0.253 \\
\hline
\end{tabular}
depend on intermediate imported inputs.

Table 13: Panel Granger non-causality test results 


\begin{tabular}{lllllll} 
France & $7.444^{* * *}$ & $3.386^{* * *}$ & 0.000 & 5.845 & 1.033 & 0.301 \\
Germany & $6.640^{* *}$ & $2.203^{* *}$ & 0.027 & 6.187 & 1.537 & 0.124 \\
Greece & 5.571 & 0.625 & 0.531 & $7.013^{* * *}$ & $2.731^{* * *}$ & 0.006 \\
Ireland & $7.160^{* * *}$ & $2.945^{* * *}$ & 0.003 & $7.732^{* * *}$ & $3.779^{* * *}$ & 0.000 \\
Italy & 4.601 & 1.929 & 0.133 & $7.105^{* * *}$ & $2.865^{* * *}$ & 0.004 \\
Latvia & $7.383^{* * *}$ & $3.270^{* * *}$ & 0.001 & 4.551 & 1.832 & 0.112 \\
Lithuania & $8.898^{* * *}$ & $5.483^{* * *}$ & 0.000 & $8.746 * * *$ & $5.260^{* * *}$ & 0.000 \\
Malta & $6.256^{* * *}$ & $5.097^{* * *}$ & 0.000 & $7.545^{* * *}$ & $7.574^{* * *}$ & 0.000 \\
Netherlands & $5.394^{* * *}$ & $3.771^{* * *}$ & 0.000 & 4.578 & 2.246 & 0.102 \\
Portugal & 5.055 & 1.144 & 0.388 & $6.899 * *$ & $2.218^{* *}$ & 0.030 \\
Slovakia & $4.808^{* *}$ & $2.514^{* *}$ & 0.011 & $4.927 * * *$ & $2.763 * * *$ & 0.005 \\
Slovenia & $8.514^{* * *}$ & $4.961^{* * *}$ & 0.000 & 6.962 & 2.985 & 0.141 \\
Spain & $4.524^{* * *}$ & $6.527^{* * *}$ & 0.000 & 2.828 & 1.532 & 0.125 \\
\hline
\end{tabular}

$*, * *$ and $* * *$ indicate indicate that the null hypothesis of non-causality is rejected at the $10 \%, 5 \%$ and $1 \%$ significant levels, respectively. The null hypothesis of the Dumitrescu and Hurlin (2012) test is no Granger causality.

\section{Conclusions}

This paper investigates the relationship between comparative advantages and export specialization in the Euro Area. We also examine the competitiveness of exports to investigate the stability of the export specialization patterns, and also investigate whether the financial crisis affected the competitive position of exporting sectors.

Findings indicate strong export competitiveness in the Netherlands, Belgium, France, and Spain. The recent financial crisis has affected the export competitiveness of countries, improving it in Portugal, Finland, Austria, the Netherlands, Estonia, Latvia, and Ireland, and worsening it in Greece, Belgium, Slovakia, Spain, France, and Cyprus. We find strong export specialization in the Netherlands, Germany, Belgium, Italy, Austria, Slovakia, France and Spain, while weak and medium export specialization in the remaining counties.

The test results suggest a long-run cointegrating relationship between comparative advantages and export specialization in all countries. In addition, our results imply that comparative advantages positively affect export specialization. Heterogeneous panel causality analysis results, imply that there is unidirectional panel causality running from comparative advantages to export specialization in Austria, Belgium, Cyprus, Estonia, Finland, France, Germany, Latvia, the Netherlands, Slovenia, and Spain; and the reverse causal relation in Greece, Italy, and Portugal. Finally, we detect a bidirectional panel causality between comparative advantages and export specialization in Ireland, Lithuania, Malta, and Slovakia. 


\section{References}

Arellano, M., Bond, S., 1991. Some tests of specification for panel data: Monte Carlo evidence and an application to employment equation. Review of Economic Studies 58(2): 277-297.

Arellano, M., Bover, O., 1995. Another look at the instrumental variable estimation of errorcomponents models. Journal of Econometrics 68: 29-51.

Arkolakis, C., Costinot, A., Rodriguez-Clare, A., 2012. New trade models, same old gains? The American Economic Review, 94-130.

Balassa, B., 1965. Trade Liberalisation and "Revealed" Comparative Advantage. The Manchester School 33(2): 99-123.

Balassa, B., Noland, M., 1989. The changing comparative advantage of Japan and the United States. Journal of the Japanese and International Economics 3: 174-188.

Bernard, A., Redding, S., Schott, P., 2007. Comparative advantage and heterogeneous firms. Review of Economic Studies 74: 31-66.

Blundell, R., Bond, S., 1998. Initial conditions and moment restrictions in dynamic panel data models. Journal of Econometrics 87: 115-143.

Bojnec, S., Ferto, I., 2015. Agri-Food export competitiveness in European Union countries. Journal of Common Market Studies 53(3): 476-492.

Cantwell, J. (1989) Technological innovation and multinational corporations. Oxford, Blackwell.

Chor, D., 2010. Unpacking sources of comparative advantage: a quantitative approach. Journal of International Economics 82: 152-67.

Costinot, A., 2009. On the origins of comparative advantage. Journal of International Economics 77: 255-264.

Cuñat, A., Melitz, M.J., 2012. Volatility, labor market flexibility, and the pattern of comparative advantage. Journal of the European Economic Association 10(2): 225-254.

Costinot, A., Donaldson, D., Komunjer, I., 2012. What goods do countries trade? A quantitative exploration of Ricardo's Ideas. Review of Economic Studies 79: 581-608.

Dalum, B., Laursen, K., Villumsen, G., 1998. Structural change in OECD export specialization Patterns: de-specialization and 'stickiness'. International Review of Applied Economics 12(3): 422-443.

Deb, K., Basu, P., 2011. Indices of revealed comparative advantage and their consistency with the Heckscher-Ohlin theory. Foreign Trade Review 46(3): 3-28.

Dumitrescu, E-I., Hurlin, C., 2012. Testing for Granger non-causality in heterogeneous panels. Economic Modelling 29: 1450-1460.

Eaton, J., Kortum, S., 2002. Technology, geography, and trade. Econometrica 70: 1741-79.

Engle, R. F., Granger C.W.J., 1987. Co-integration and error correction: representation, estimation, and testing. Econometrica 55: 251-276.

Esposito, P., 2017. Trade creation, trade diversion and imbalances in the EMU. Economic Modelling 60: 462-472.

Granger, C.W.J., 1969. Investigating causal relations by econometric models and crossspectral models. Econometrica 37: 424-438.

Grosssman, G.M., Helpman, E., 1991. Trade, knowledge spillovers, and growth. European Economic Review 35: 517-526.

Im, K. S., Pesaran, M. H., Shin, Y., 2003. Testing for unit roots in heterogeneous panels. Journal of Econometrics 115: 53-74.

Kapetanios, G., Pesaran, M.H., Yamagata, T., 2011. Panels with non-stationary multifactor error structures. Journal of Econometrics 160: 326-348.

Kerr, W.R., 2013. Heterogeneous Technology diffusion and Ricardian trade patterns. NBER Working Paper Series, No. 19657.

Konstantakopoulou, I., Tsionas, E.G., 2017. The long-run causal relationship between exports and economic growth in the Euro Area. Applied Economics Letters 24(8): 536-539.

Konstantakopoulou, I., 2017. The aggregate exports-GDP relation under the prism of infrequent trend breaks and multi-horizon causality. International Economics and Economic Policy 14(4): 661-689.

Konya, L., 2006. Exports and growth: Granger causality analysis on OECD countries with a panel data approach. Economic Modelling 23: 978-992. 
Krugman, P., 1987. The narrow moving band, the Dutch disease, and the competitive consequences of Mrs. Thatcher: Notes on trade in the present of dynamic scale economies. Journal of Development Economics 27: 41-55.

Kunst, R.M., Marin, D., 1989. On exports and productivity: A causal analysis. Review of Economics and Statistics 71: 699-703.

Laursen, K., 1998. Revealed comparative advantage and the alternatives as measures of international specialization. DRUID Working Paper 98-30. Copenhagen.

Laursen, K., 2000. Trade specialization, technology and economic growth: Theory and evidence from advanced countries. Cheltenham: Edward Elgar.

Lee, J., 2011. Export specialization and economic growth around the world. Economic Systems 35: 45-63.

Levchenko, A., 2007. Institutional quality and international trade. Review of Economic Studies 74: 791-819.

Levchenko, A.A., Zhang, J., 2016. The evolution of comparative advantage: Measurement and welfare implications. Journal of Monetary Economics 78: 96-111.

Levin, A., Lin, C-F., Chu C-J. J., 2002. Unit root tests in panel data: asymptotic and finitesample properties. Journal of Econometrics 108: 1-24.

Mallick, S., Marques, H., 2016. Pricing strategy of emerging market exporters in alternate currency regimes: The role of comparative advantage. International Review of Economics and Finance 45: 68-81.

Nieminen, M., 2015. Trade imbalances within the euro area and with respect to the rest of the world. Economic Modelling 48: 306-314.

Nunn, N., Trefler, D., 2014. Domestic institutions as a source of comparative advantage. Handbook of International Economics 5: 263-315.

Oelgemoller, J., 2013. Revealed comparative advantages in Greece, Ireland, Portugal and Spain. Intereconomics 48(4): 243-253.

Pearson, J., Viviers, W., Cuyvers, L., Naude, W., 2010. Identifying export opportunities for South Africa in the southern engines: A DSM approach. International Business Review 19: 345359.

Pedroni, P., 2000. Fully Modified OLS for Heterogeneous Cointegrated Panels. Advances in Econometrics 15: 93-130.

Phillips, P.C.B., Hansen, B.E., 1990. Statistical Inference in Instrumental Variable Regression with I(1) Processes. Review of Economic Studies 57: 99-125.

Pesaran, M. H., 2006. Estimation and inference in large heterogeneous panels with a multifactor error structure. Econometrica 74(4): 967-1012.

Pesaran, M.H., 2007. A simple panel unit root test in the presence of cross-section dependence. Journal of Applied Econometrics 22: 265-312.

Ohnsorge, F., Trefler, D., 2007. Sorting it Out: International trade with heterogeneous workers. Journal of Political Economy 115(5): 868-892.

Ramos, F.R., 2001. Exports, imports, and economic growth in Portugal: evidence from causality and cointegration analysis. Economic Modelling 18: 613-623.

Richardson, D., Zhang, C., 1999. Revealing comparative advantage: Chaotic or coherent patterns across time and sector and U.S. trading partner? National Bureau of Economic Research, Working Paper No. 7212.

Rivera-Batiz, L.A., Romer, P.M., 1991a. Economic integration and endogenous growth. Quarterly Journal of Economics 106: 531-555.

Rivera-Batiz, L.A., Romer, P.M., 1991b. International trade and endogenous technical change. European Economic Review 35: 971-1004.

Romalis, J., 2004. Factor proportions and the structure of commodity trade. American Economic Review 94: 67-97.

Trefler, D., 1995. The case of missing trade and other mysteries. American Economic Review 85(5): 1029-1046.

Young, A., 1991. Learning by doing and the dynamic effects of international trade. Quarterly Journal of Economics 106(2): 369-406.

Yue, C., Hua, P., 2002. Does comparative advantage explains export patterns in China?. China Economic Review 13: 276-296. 